\title{
Physico-chemical form of trace metals accumulated by phytoplankton and their assimilation by filter-feeding invertebrates
}

\author{
T. Y.-T. Ng $^{1}$, C. Amiard-Triquet ${ }^{2}$, P. S. Rainbow ${ }^{3, *}$, J. C. Amiard ${ }^{2}$, W.-X. Wang ${ }^{1}$ \\ ${ }^{1}$ Department of Biology, The Hong Kong University of Science and Technology (HKUST), Clear Water Bay, \\ Kowloon, Hong Kong, SAR \\ ${ }^{2}$ ISOMer, SMAB, Service d'écotoxicologie, 2 rue de la Houssinière, BP 92208, 44322 Nantes Cedex 3, France \\ ${ }^{3}$ Department of Zoology, The Natural History Museum, Cromwell Road, London SW7 5BD, UK
}

\begin{abstract}
This study investigated whether the nature of the binding of the trace metals cadmium, silver and zinc accumulated by phytoplankton can affect their subsequent assimilation efficiencies (AE) in 3 filter-feeding benthic invertebrates, the green mussel Perna viridis, the clam Ruditapes philippinarum and the barnacle Balanus amphitrite. Seven phytoplankton species were chosen from a wide systematic range to ensure large differences in the partitioning of their accumulated trace metals into 3 fractions: (1) exchangeable metal adsorbed on the outside of the cells, as defined by extraction with the chelating agent 8-hydroxyquinoline-5-sulphonate; $(2)$ incorporated metal that is in a soluble form; and (3) insoluble incorporated metal. There were few significant correlations between $\mathrm{AE}$ and the percentage of phytoplankton metal incorporated into any 1 fraction or combination of fractions. There is no support, therefore, for a generalised conclusion that any of the 3 fractions isolated represents the sole form of phytoplankton metal that is bioavailable for trophic transfer to a herbivore. Even trace metals bound to the insoluble fraction in phytoplankton may be bioavailable to herbivores. Furthermore, there were no consistent effects of phytoplankton concentration on metal AEs in 1 of the herbivores - P. viridis. There was no evidence that the AE of any of the 3 trace metals was changed when the herbivores were feeding on the phytoplankton species (Thalassiosira weissflogii) on which they were fed during acclimation.
\end{abstract}

KEY WORDS: Trace metal assimilation · Phytoplankton $\cdot$ Filter-feeding invertebrates

\section{INTRODUCTION}

It is appreciated that many marine invertebrates gain a significant (often majority) part of their intake of trace metals from their food supply rather than from solution, and filter-feeding benthic invertebrates ingesting phytoplankton are no exception (Wang 2002). Clearly the total amount of metals accumulated by phytoplankton will affect the quantity of trace metals transferred trophically to the invertebrates, but the nature of the binding of metals in the phytoplankton also has the potential to have a significant effect on trophic transfer (Reinfelder \& Fisher 1991, AmiardTriquet et al. 1993, Wang \& Fisher 1999, Chong \& Wang 2000, Wang 2002).
Reinfelder \& Fisher (1991) first demonstrated a linear 1:1 relationship between the metal assimilated by marine copepods from a diet of diatoms and the metal partitioned in the cytoplasm of the ingested diatoms. There were also later extensive studies into this relationship in bivalves and copepods (Hutchins et al. 1995, Wang \& Fisher 1996, Xu \& Wang 2002, 2004), but still no generalisations can be made on the relationship between metal partitioning in phytoplankton and metal assimilation in the herbivores feeding on them. In particular, very few comprehensive studies have attempted to study this relationship in several marine herbivores feeding on different phytoplankton species simultaneously.

To study the metal distribution in the phytoplankton, the phytoplankton is conventionally separated into 
several fractions by differential centrifugation (Fisher et al. 1983, Reinfelder \& Fisher 1991) - the heaviest fraction (cell walls and membranes), the moderate fraction (organelles) and the lightest fraction or the supernatant (cytoplasm). In this study, we investigated the subcellular metal distribution in 7 different phytoplankton species (2 diatoms, 1 dinoflagellate and 4 flagellates). We separated the phytoplankton into 3 fractions: (1) exchangeable metal adsorbed on the outside of the cells, as defined by extraction with the chelating agent 8-hydroxyquinoline-5-sulphonate (after Price \& Morel 1990); (2) incorporated metal that is in a soluble form; and (3) insoluble incorporated metal. This fractionation scheme is somewhat different from that frequently used in the past: the division into cytoplasmic versus cell-wall fractions. In the present study we have investigated the bioavailability of the easily exchangeable fraction that is rarely examined. Metals adsorbed on the cell walls of phytoplankton are very reactive and may be bioavailable to filter-feeding herbivores. In addition, we have combined the cellwall fractions and organelles, to form the insoluble fraction, while the soluble fraction consists of cytosol.

We seek generalities in the relationships between metal partitioning in phytoplankton and the trophic transfer of trace metals from phytoplankton to filterfeeding herbivores, as indicated by the assimilation efficiencies (AEs) of the trace metals. We employed 3 filter-feeding benthic invertebrates, namely the green mussel Perna viridis, the clam Ruditapes philippinarum and the barnacle Balanus amphitrite, for each of which we have considerable experience in measuring AEs (Chong \& Wang 2001, Rainbow et al. 2003, 2004, Shi et al. 2003, Ng \& Wang 2004, Shi \& Wang 2004). We chose 7 phytoplankton species from a wide range of systematic groupings, in order to increase the chances of large differences in the fractionation of accumulated trace metals in the phytoplankton and, thus, to increase the variations of AEs. We have used 3 trace metals-cadmium, zinc and silver, which have gamma-emitting radioisotopes suitable for simultaneous counting in experiments. We also investigated the effects of phytoplankton concentration on metal AEs in 1 of the herbivores $-P$. viridis. Finally, we took the opportunity to see whether AEs were raised when the herbivores were feeding on the phytoplankton species (Thalassiosira weissflogii), on which they were fed during acclimation.

\section{MATERIALS AND METHODS}

Phytoplankton cultures. Seven phytoplankton species (Table 1), originating from the Provasoli-Guillard National Centre for Culture of Marine Phytoplankton,
Table 1. Cell dimensions of the phytoplankton species used in the metal-assimilation experiments, with accession numbers from the Provasoli-Guillard National Centre for Culture of Marine Phytoplankton (CCMP). Cell density measured at the end of the radiolabelling is also given (mean $\pm \mathrm{SD}, \mathrm{n}=3$ experiments)

\begin{tabular}{|c|c|c|}
\hline & $\begin{array}{l}\text { Cell dimensions } \\
\qquad(\mu \mathrm{m})\end{array}$ & $\begin{array}{l}\text { Cell density } \\
\left(10^{6} \text { cells ml } \mathrm{ml}^{-1}\right)\end{array}$ \\
\hline \multicolumn{3}{|l|}{ Bacillariophyceae (diatoms) } \\
\hline $\begin{array}{l}\text { Thalassiosira weissflogii } \\
\text { (CCMP 1587) }\end{array}$ & $8-10 \times 14-18$ & $0.10 \pm 0.01$ \\
\hline $\begin{array}{l}\text { Phaeodactylum tricornut } \\
\text { (CCMP 630) }\end{array}$ & $4-5 \times 24-29$ & $3.06 \pm 0.36$ \\
\hline \multicolumn{3}{|c|}{ Dinophyceae (dinoflagellates) } \\
\hline $\begin{array}{l}\text { Prorocentrum minimum } \\
\text { (CCMP 696) }\end{array}$ & $10-12 \times 13-16$ & $0.06 \pm 0.01$ \\
\hline \multicolumn{3}{|l|}{ Prasinophyceae } \\
\hline $\begin{array}{l}\text { Tetraselmis sp. } \\
\text { (CCMP 896) }\end{array}$ & $6-10 \times 10-12$ & $0.36 \pm 0.17$ \\
\hline \multicolumn{3}{|l|}{ Chlorophyceae } \\
\hline $\begin{array}{l}\text { Dunaliella tertiolecta } \\
\text { (CCMP 1320) }\end{array}$ & $1-3 \times 6-9$ & $0.48 \pm 0.17$ \\
\hline $\begin{array}{l}\text { Prymnesiophyceae } \\
\text { Isochrysis galbana } \\
\text { (CCMP 1323) }\end{array}$ & $2-4 \times 4-6$ & $1.93 \pm 0.08$ \\
\hline $\begin{array}{l}\text { Cryptophyceae } \\
\text { Rhodomonas salina } \\
\text { (CCMP 1319) }\end{array}$ & $6-8 \times 5-13$ & $0.68 \pm 0.07$ \\
\hline
\end{tabular}

were batch-cultured in $f / 2$ medium (Guillard \& Ryther 1962) at $18^{\circ} \mathrm{C}$ (Thalassiosira weissflogii, Phaeodactylum tricornutum, Tetraselmis sp., Dunaliella tertiolecta) and $24^{\circ} \mathrm{C}$ (Prorocentrum minimum, Isochrysis galbana, Rhodomonas salina) and a light illumination of $100 \mu \mathrm{mol} \mathrm{m} \mathrm{m}^{-2} \mathrm{~s}^{-1}$ with a $14 \mathrm{~h}$ light:10 h dark cycle. The phytoplankton with different growth rates were cultured at 2 temperatures, in order to reach the late exponential phase simultaneously.

Filter-feeding invertebrates. Three filter-feeding benthic invertebrates were used in this study -2 bivalves, Perna viridis and Ruditapes philippinarum, and the barnacle Balanus amphitrite. B. amphitrite was collected from Tung Chung on Lantau Island, Hong Kong, whereas $P$. viridis and $R$. philippinarum were collected from Tolo Harbour, Hong Kong. Mussels were cleaned of epibionts, and individual barnacles were isolated on small pieces of mussel shell. In the laboratory, the invertebrates were maintained at $23^{\circ} \mathrm{C}$ in aerated seawater (33 psu salinity) and fed the diatom Thalassiosira weissflogii for $>1$ wk before experiments began.

Radiotracers. Radioisotopes ${ }^{110 \mathrm{~m}} \mathrm{Ag}\left(t_{1 / 2}=249.8 \mathrm{~d}\right)$, ${ }^{109} \mathrm{Cd}\left(t_{1 / 2}=462 \mathrm{~d}\right)$ and ${ }^{65} \mathrm{Zn}\left(t_{1 / 2}=244 \mathrm{~d}\right)$ were obtained from New England Nuclear, Boston, USA, or Riso National Laboratory, Denmark. Counting of phytoplankton fractions and individual live animals was car- 
ried out on a Wallac gamma counter. Spillover of radioisotopes was corrected, and all counts were related to standards for each isotope. The gamma emissions of ${ }^{110 \mathrm{~m}} \mathrm{Ag}$ were determined at $658 \mathrm{keV},{ }^{109} \mathrm{Cd}$ at $88 \mathrm{keV}$, and ${ }^{65} \mathrm{Zn}$, at $1115 \mathrm{keV}$, and counting times were adjusted so that the propagated counting errors were typically $<5 \%$.

Phytoplankton metal labelling. For 3 of 4 experiments, each phytoplankton species was radiolabelled with the 3 metal radioisotopes simultaneously in 4 replicated bottles ( 1 bottle for radioactive pulse feeding to the invertebrates and 3 bottles for determination of metal subcellular fractionation). Cultures were replicated on 4 different dates, to be ready, in turn, to be fed to the filter-feeding invertebrates in 4 separate experiments. The phytoplankton was radiolabelled as described in Wang \& Rainbow (2000). Briefly, the phytoplankton cells were collected by centrifugation at $3836 \times g$ for $15 \mathrm{~min}$, except Thalassiosira weissflogii, which was recovered by filtration (pore size: $3 \mu \mathrm{m})$. The cells were then resuspended in $0.2 \mu \mathrm{m}$ filtered seawater enriched with $f / 2$ levels of $N, P, S i$ and vitamins and with $f / 20$ levels of trace metals minus EDTA, Cu and Zn (Guillard \& Ryther 1962). Each radioisotope was added at 0.2 to $0.75 \mu \mathrm{Ci}(\mathrm{Ag})$, 0.1 to $0.75 \mu \mathrm{Ci}(\mathrm{Cd})$, or 0.2 to $0.75 \mu \mathrm{Ci}(\mathrm{Zn})$ (radioactivity varied for mussel, clam and barnacle experiments) on Day 0 for ${ }^{109} \mathrm{Cd}$ and ${ }^{65} \mathrm{Zn}$ and on Day 4 for ${ }^{110 \mathrm{~m}} \mathrm{Ag}$. The phytoplankton were grown for $5 \mathrm{~d}$, allowing the cells to be uniformly radiolabelled.

On Day 5, the phytoplankton were collected by a similar method to that described above. The cell density was counted microscopically. Aliquots of each culture of each phytoplankton species were then added to the feeding containers (see 2 subsections below) to give suspended phytoplankton concentrations of either 0.5 or $3 \mathrm{mg} \mathrm{l}^{-1}$ for each species. Phytoplankton were also collected for fractionation analysis (3 replicates per flask). Preliminary tests showed that Day 5 corresponds to the exponential phase in all species except in the case of Prorocentrum minimum, the growth of which proved slightly slower.

Phytoplankton metal fractionation analysis. Phytoplankton cells to be used to assess metal partitioning (3 replicates in each of 3 experiments, except for Perna viridis at $3 \mathrm{mg} \mathrm{l}^{-1}$ ) were resuspended for $10 \mathrm{~min}$ in $20 \mathrm{ml}$ of a chelating agent (8-hydroxyquinoline-5-sulphonate, $1 \mathrm{mM}$ ) to extract any exchangeable metals loosely bound onto the cell wall, according to the method of Price \& Morel (1990). The phytoplankton was centrifuged again $(2180 \times g$ for 20 min at $20^{\circ} \mathrm{C}$ ), and the supernatant (S1 containing exchangeable radiolabelled metals) and the pellet (P1 containing incorporated radiolabelled metals) were separated. The metal fractionation of these pellets into the insoluble fraction (P2) and cytosol (S2) was completed according to the procedure described by Ettajani et al. (2001). Gamma counting was carried out on P1, P2, S1 and S2.

Assimilation experiments. The AEs of the 3 metals in the invertebrates were determined with a pulse-chase feeding technique, as described in Wang \& Fisher (1999) and Wang \& Rainbow (2000). Then, 8 bivalves or 10 barnacles were placed in $500 \mathrm{ml}$ (bivalves) or $100 \mathrm{ml}$ (barnacles) of $0.2 \mu \mathrm{m}$ filtered seawater and fed (30 min for bivalves, $2 \mathrm{~h}$ for the smaller barnacles) on each of the radiolabelled phytoplankton at a cell density of $0.5 \mathrm{mg} \mathrm{l}^{-1}$ (all 3 invertebrates) or $3 \mathrm{mg} \mathrm{l}^{-1}$ (Perna viridis only). The first phytoplankton concentration represents typical phytoplankton concentrations in Hong Kong waters; the second concentration is the maximum phytoplankton concentration at which $P$. viridis does not produce pseudofaeces. Individual invertebrates were rinsed with non-radiolabelled water, and their radioactivity was counted. The 5 individuals (up to 8 for some barnacle samples) with the highest counts in each feeding treatment were chosen for AE estimation. The bivalves were placed in individual containers in a 101 enclosed recirculating aquarium and fed with unlabelled diatoms (Thalassiosira weissflogii) to promote depuration of ingested radiolabelled food. The radioactivity in each bivalve was counted at frequent time intervals over $48 \mathrm{~h}$. At each count faecal pellets were removed to minimise desorption of radiotracers from faecal material, and the aquarium was covered to prevent light disturbance. The barnacles were placed individually in beakers containing $100 \mathrm{ml}$ filtered seawater and fed with unlabelled $T$. weissflogii. The radioactivity remaining in each barnacle was measured at frequent time intervals over a period of $48 \mathrm{~h}$; faeces were removed, and water and food were renewed at each count. All experiments were carried out at $23^{\circ} \mathrm{C}$ using filtered $(0.2 \mu \mathrm{m})$ seawater at $33 \mathrm{psu}$ salinity.

\section{RESULTS}

\section{Metal accumulation in phytoplankton}

Metal accumulation in the phytoplankton was estimated from all 3 replicates of each of 3 cultures for each species. The concentration factor $\left(\mathrm{l} \mathrm{g}^{-1}\right)$ is the ratio of the total radioactivity in all 3 fractions (exchangeable, soluble and insoluble) of the phytoplankton over the radioactivity in the culture medium. The phytoplankton species had significantly different metal accumulation concentration factors $(p<0.001)$. Thalassiosira weissflogii had the highest 
cadmium, zinc and silver concentration factors, and the silver concentration factor of Prorocentrum minimum was not significantly different from that of T. weissflogii (Fig. 1). All the other phytoplankton species had comparable metal concentration factors. The ranges of concentration factors were 6 to $63 \mathrm{l} \mathrm{g}^{-1}$ for cadmium, 6 to $64 \mathrm{l} \mathrm{g}^{-1}$ for zinc and 3 to $39 \mathrm{l} \mathrm{g}^{-1}$ for silver.
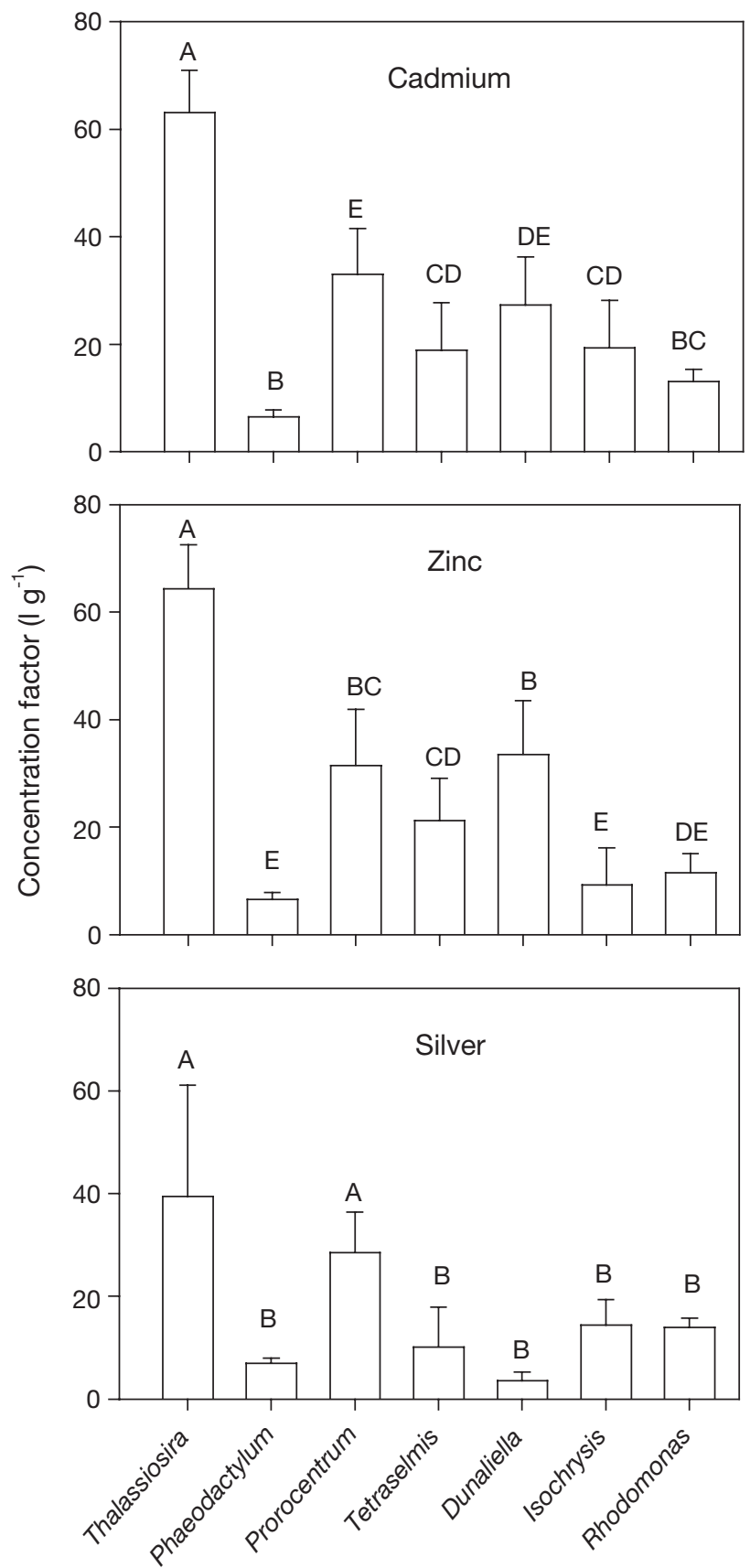

Fig. 1. Concentration factors $\left(\mathrm{l} \mathrm{g}^{-1}\right)$ of cadmium, zinc and silver in 7 species of phytoplankton. Means and standard deviations $(\mathrm{n}=9)$. For each metal, means that share a letter were not significantly different

\section{Metal fractionation in phytoplankton}

The distributions of labelled $\mathrm{Cd}, \mathrm{Zn}$ and $\mathrm{Ag}$ in exchangeable, soluble and insoluble fractions are depicted in Fig. 2. The percentage of exchangeable cadmium was low for all the species except Prorocentrum minimum, in which it reached $21 \%$. For $\mathrm{Zn}$, the most important exchangeable fraction was also detected in $P$. minimum $(31 \%)$, but it was also relatively high in Thalassiosira weissflogii $(23 \%)$ and Rhodomonas salina (16\%). On the other hand, no zinc was detectable in the exchangeable fraction of Phaeodactylum tricornutum. In most of the species, however, an important part of the silver taken up was present in the exchangeable fraction, particularly in Isochrysis galbana $(59 \%)$, although in contrast little silver $(<10 \%)$ was exchangeable in $P$. tricornutum and $R$. salina.

The distribution of metals readily incorporated in the phytoplankton cells between soluble and insoluble fractions was also species-dependent (Fig. 2, Table 2). Incorporated cadmium was mainly present in insoluble form in the diatoms and the dinoflagellate, whereas all other species stored this element mainly in soluble form $_{i}$ this was less distinctly so in Rhodomonas salina. The distribution pattern between soluble and insoluble fractions was relatively similar for zinc, except for $R$. salina, which stored most zinc in insoluble form. The distribution pattern of silver again showed a predominance of storage in insoluble form in the diatoms and the dinoflagellate. In the other species, incorporated silver was distributed relatively equally between soluble and insoluble forms, with the exception of Dunaliella tertiolecta, which stored silver mainly in the soluble fraction.

\section{Assimilation efficiencies}

Four experiments measured the AEs of $\mathrm{Cd}, \mathrm{Zn}$ and Ag in 3 filter-feeding invertebrates - the green mussel Perna viridis, the clam Ruditapes philippinarum and the barnacle Balanus amphitrite, feeding on up to 7 phytoplankton species. All 3 filter feeders were presented with each phytoplankton species at a concentration of $0.5 \mathrm{mg} \mathrm{l}^{-1}$. The green mussel was also presented with phytoplankton at $3 \mathrm{mg} \mathrm{l}^{-1}$. In the event there was insufficient radioactivity present to measure Ag assimilation in $P$. viridis feeding on any of the phytoplankton at the lower concentration. The barnacles did not feed on either Isochrysis galbana or Rhodomonas salina. Figs. 3 to 5 show the mean retention of $\mathrm{Cd}, \mathrm{Zn}$ and $\mathrm{Ag}$ (where appropriate) in $P$. viridis at the 2 phytoplankton concentrations and in $R$. philippinarum and B. amphitrite at $0.5 \mathrm{mg} \mathrm{l}^{-1}$, broken down by individual phytoplankton species as 

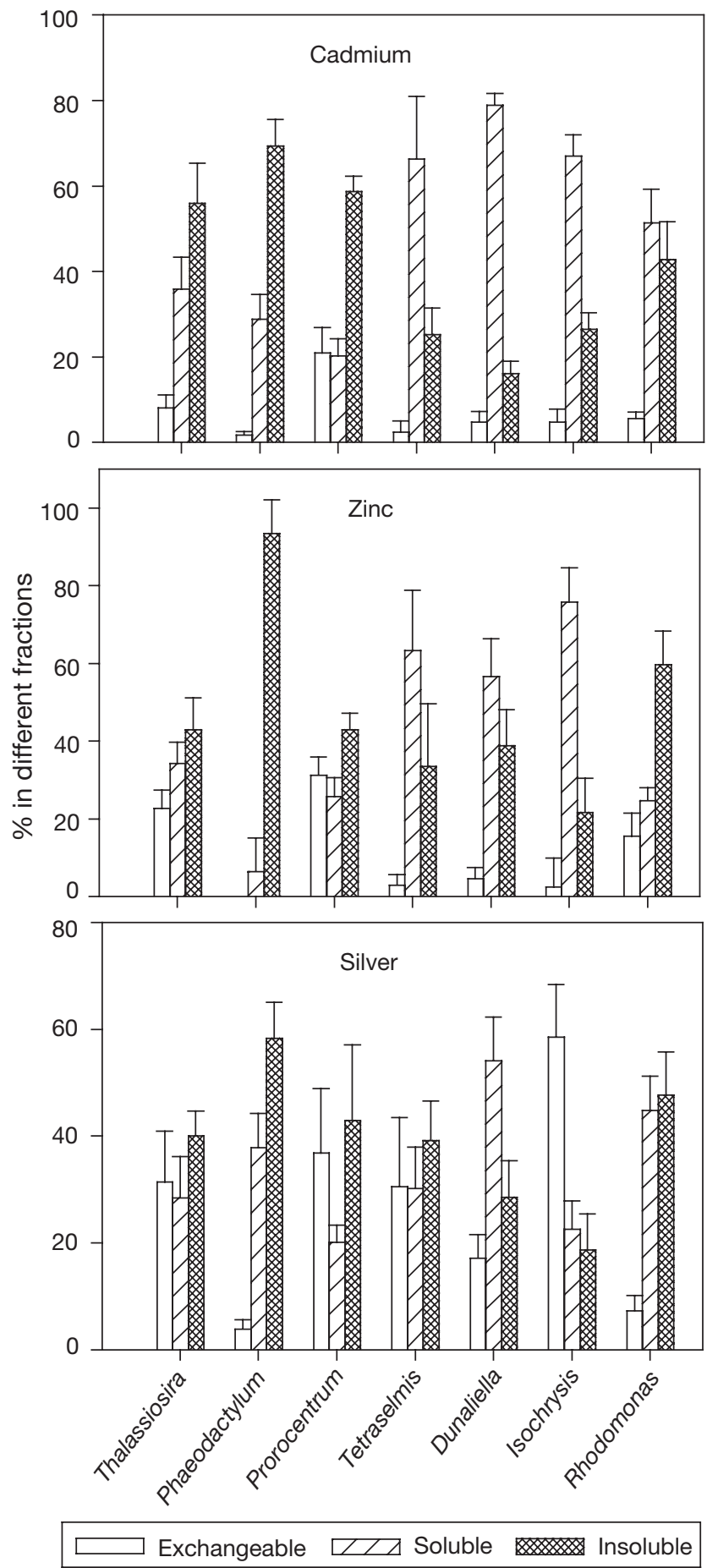

Fig. 2. Percentage distributions of labelled cadmium, zinc and silver in 3 fractions (exchangeable, soluble, insoluble) in 7 phytoplankton species. Mean percentages and standard deviations $(\mathrm{n}=9)$

food sources. The AEs of metals from phytoplankton in different herbivores are shown in Fig. 6. AE was determined as the percentage of initial radioactivity retained in the barnacles after $24 \mathrm{~h}$ (Wang \& Rain- bow 2000, Rainbow et al. 2003, 2004), but after $48 \mathrm{~h}$ in the mussels and clams, the longer period for the bivalves being in line with earlier work in the laboratory (Chong \& Wang 2001, Shi et al. 2003, Ng \& Wang 2004).

Statistical details from Figs. 3 to 6 are shown in Table 3. There were significant differences in AEs of $\mathrm{Cd}$ and $\mathrm{Zn}$ (but not Ag) between the invertebrates feeding on the same phytoplankton species at the same concentration (Table 3a, Fig. 6), for each invertebrate feeding on the different phytoplankton species at the same concentration (Table 3b, Fig. 6), and between the $\mathrm{Cd}$ and $\mathrm{Zn}$ AEs of the same species (Perna viridis) feeding on the same phytoplankton species at different concentrations (Table 3c, Fig. 6). Generally the green mussel $P$. viridis had the lowest AEs for both $\mathrm{Cd}$ and $\mathrm{Zn}$ of the 3 invertebrates feeding on phytoplankton at $0.5 \mathrm{mg} \mathrm{l}^{-1}$, and the $\mathrm{Cd}_{1} \mathrm{Zn}$ and Ag AEs of Ruditapes philippinarum were never significantly exceeded by the AE of another invertebrate (Table 3a, Fig. 6).

Perna viridis showed no significant difference in Cd AE between phytoplankton species at high concentration, nor in Zn AE between phytoplankton at low concentration (Table 3b, Fig. 6). There were significant a priori differences in $\mathrm{Cd} \mathrm{AE}$ between phytoplankton at low concentration, in $\mathrm{Zn} \mathrm{AE}$ at high concentration and in Ag AE at high concentration, but in the former 2 cases the effect was not strong enough to distinguish diets a posteriori (Table 3b, Fig. 6). Ruditapes philippinarum showed no significant differences in Zn or Ag AEs between phytoplankton diets, but $\mathrm{Cd}$ AE did vary significantly (Table 3b, Fig. 6). Balanus amphitrite showed significant differences in AE between phytoplankton diets for $\mathrm{Cd}$ and $\mathrm{Zn}$, but not for $\mathrm{Ag}$ (Table 3b, Fig. 6).

In 12 of 14 comparisons (Table 3c), there was no significant difference between the $\mathrm{Cd}$ and $\mathrm{Zn}$ AEs of Perna viridis feeding at low $\left(0.5 \mathrm{mg} \mathrm{l}^{-1}\right)$ and high (3 mg $\mathrm{l}^{-1}$ ) phytoplankton concentrations. The 2 exceptions did not follow the same pattern. The Cd AE of $P$. viridis feeding on Rhodomonas salina was higher in the lowdiet mussels, but the $\mathrm{Zn}$ AE of $P$. viridis feeding on Prorocentrum minimum was higher in the high-diet mussels (Table 3c).

The 3 herbivores had been feeding on the diatom Thalassiosira weissflogii prior to the experiments. As Table $3 \mathrm{~b}$ and Fig. 6 show, there was no evidence that the AE of any of the 3 metals was raised significantly above all others when the experimental food source was also T. weissflogii. It is true, however, that the AE of each metal when an invertebrate was feeding on T. weissflogii was only exceeded once-in the case of the Ag AE of Perna viridis feeding on Phaeodactylum tricornutum at high concentration. 
Table 2. Comparisons (ANOVA and Tukey multiple-comparison tests) between distribution of Cd, $\mathrm{Zn}$ and Ag in 7 species of phytoplankton, using arcsine-transformed percentage data. Columns under the a posteriori heading sharing the same letter within a row are not different from each other $(\mathrm{p}>0.05) .{ }^{* * *} \mathrm{p}<0.001$

\begin{tabular}{|c|c|c|c|c|c|c|c|c|c|c|}
\hline & \multicolumn{2}{|c|}{ ANOVA } & \multirow{2}{*}{$\begin{array}{l}\text { a priori } \\
\text { p }\end{array}$} & \multirow[b]{2}{*}{$\begin{array}{l}\text { Thalas- } \\
\text { siosira }\end{array}$} & \multirow[b]{2}{*}{$\begin{array}{c}\text { Phaeo- } \\
\text { dactylum }\end{array}$} & \multirow[b]{2}{*}{$\begin{array}{l}\text { Proro- } \\
\text { centrum }\end{array}$} & \multirow{2}{*}{$\begin{array}{l}\text { a posteriori } \\
\text { Tetra- } \\
\text { selmis }\end{array}$} & \multirow[b]{2}{*}{$\begin{array}{l}\text { Duna- } \\
\text { liella }\end{array}$} & \multirow[b]{2}{*}{$\begin{array}{c}\text { Iso- } \\
\text { chrysis }\end{array}$} & \multirow[b]{2}{*}{$\begin{array}{l}\text { Rhodo } \\
\text { monas }\end{array}$} \\
\hline & $F$ & $\mathrm{df}$ & & & & & & & & \\
\hline \multicolumn{11}{|l|}{ Cadmium } \\
\hline Exchangeable & 30.166 & 6,56 & $0000^{* * *}$ & B & $\mathrm{D}$ & A & D & $\mathrm{B}, \mathrm{C}, \mathrm{D}$ & C, D & $\mathrm{B}, \mathrm{C}$ \\
\hline Soluble & 75.354 & 6,56 & $0.000^{* * *}$ & D & $\mathrm{D}, \mathrm{E}$ & E & B & A & B & $\mathrm{C}$ \\
\hline Insoluble & 51.202 & 6,56 & $0.000^{* * *}$ & $\mathrm{~B}, \mathrm{C}$ & $\mathrm{D}$ & C, D & A & A & A & B \\
\hline \multicolumn{11}{|l|}{ Zinc } \\
\hline Exchangeable & 60.794 & 6,56 & $0.000^{* * *}$ & $\mathrm{D}, \mathrm{E}$ & $\mathrm{C}$ & $\mathrm{D}$ & A, B & A & $\mathrm{B}, \mathrm{C}$ & E \\
\hline Soluble & 58.871 & 6,56 & $0.000^{* * *}$ & D & A & D & $\mathrm{B}, \mathrm{C}$ & B & $\mathrm{C}$ & D \\
\hline Insoluble & 51.864 & 6,56 & $0.000^{* * *}$ & B, C & A & B, C & $C, D$ & $\mathrm{C}$ & D & B \\
\hline \multicolumn{11}{|l|}{ Silver } \\
\hline Exchangeable & 50.674 & 6,55 & $0.000^{* * *}$ & D & $\mathrm{C}$ & $\mathrm{D}$ & $\mathrm{D}$ & A & B & $\mathrm{C}$ \\
\hline Soluble & 30.167 & 6,55 & $0.000^{* * *}$ & $C, D, E$ & A & E & $\mathrm{B}, \mathrm{C}$ & C, D & D & $\mathrm{A}, \mathrm{B}$ \\
\hline Insoluble & 21.197 & 6,55 & $0.000^{* * *}$ & B, C & A & B & $\mathrm{B}, \mathrm{C}$ & C, D & D & $\mathrm{A}, \mathrm{B}$ \\
\hline
\end{tabular}
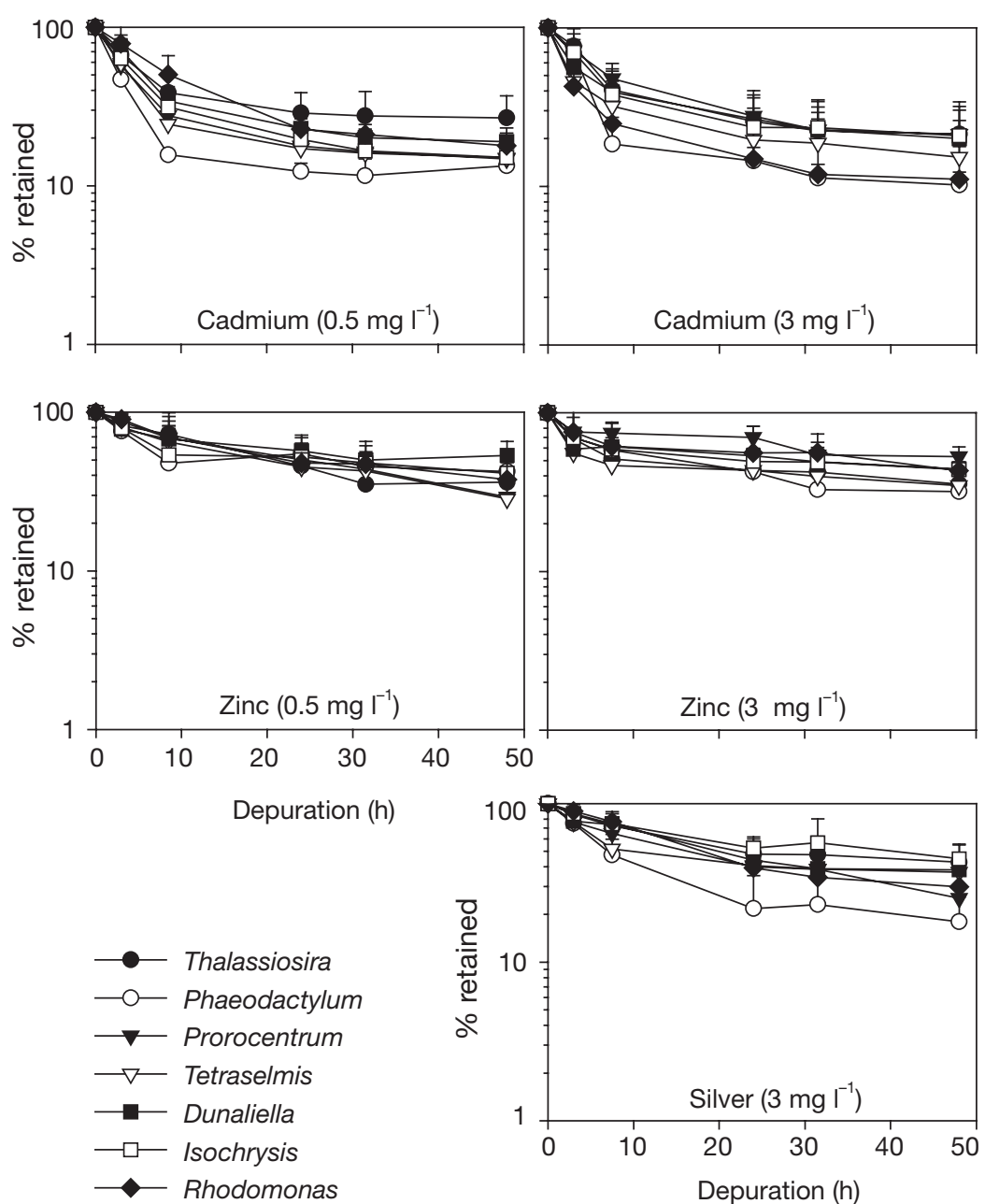

Fig. 3. Perna viridis. Retention of cadmium, zinc and silver ( $3 \mathrm{mg} \mathrm{l}^{-1}$ only) by green mussels following pulse-feeding on each of 7 phytoplankton species at 0.5 and $3 \mathrm{mg} \mathrm{l}^{-1}$. Means and standard deviations $(\mathrm{n}=5)$

\section{Phytoplankton metal fractionation and assimilation efficiencies}

Correlations were sought between characteristics of the fractionation of accumulated $\mathrm{Cd}, \mathrm{Zn}$ and $\mathrm{Ag}$ in the 7 phytoplankton species and the subsequent $\mathrm{AE}$ of the metal by each of the filter feeders. Out of a potential 48 correlations in the whole data set, only 8 were significant, and details of these are presented in Table 4.

The AE of Ag in Perna viridis feeding at $3 \mathrm{mg} \mathrm{l}^{-1}$ (but not at $0.5 \mathrm{mg} \mathrm{l}^{-1}$ ) correlated positively with the percentage of exchangeable Ag in the phytoplankton (Table 4); this correlation caused a similar correlation in the combination of soluble and exchangeable fractions. The negative correlation of the $\mathrm{AE}$ with the percentage of $\mathrm{Ag}$ content in insoluble form is a mathematical consequence of this latter positive correlation. In the case of the $\mathrm{AE}$ of $\mathrm{Cd}$ in Ruditapes philippinarum, there was a positive correlation with the percentage of phytoplankton Cd in soluble form (Table 4), carried forward to a similar correlation with the combined soluble and exchangeable fractions. The barnacle Balanus amphitrite showed a negative correlation between $\mathrm{Cd} A \mathrm{AE}$ and the percentage of phytoplankton $\mathrm{Cd}$ in exchangeable form (Table 4). On the other hand, the Zn AE 

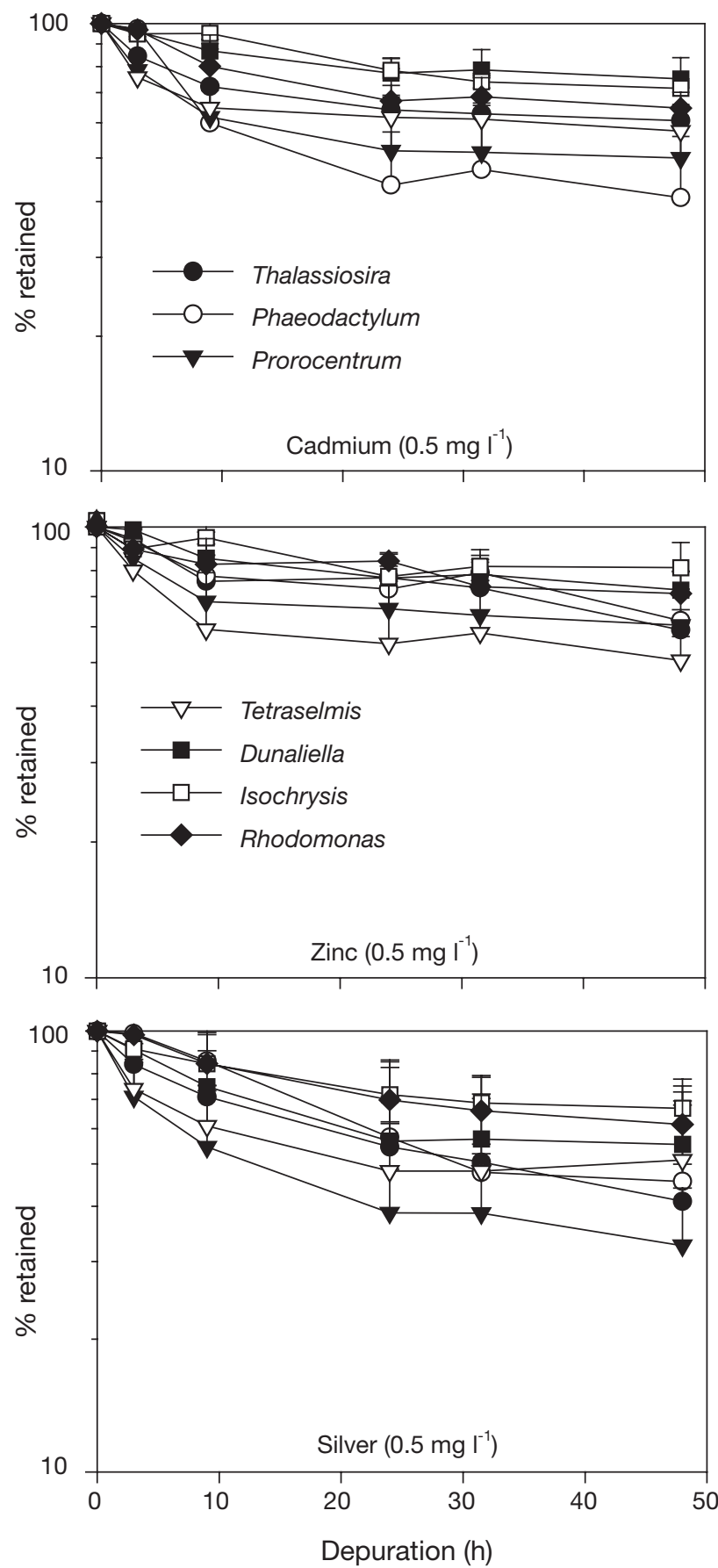

Fig. 4. Ruditapes philippinarum. Retention of cadmium, zinc and silver by clams following pulse-feeding on each of 7 phytoplankton species at $0.5 \mathrm{mg} \mathrm{l}^{-1}$. Means and standard deviations $(\mathrm{n}=5)$

of $B$. amphitrite showed a positive correlation with the percentage of phytoplankton $\mathrm{Zn}$ in exchangeable form, but a negative correlation with the percentage of soluble phytoplankton Zn (Table 4). The latter negative correlation was maintained when soluble and exchangeable fractions were combined.
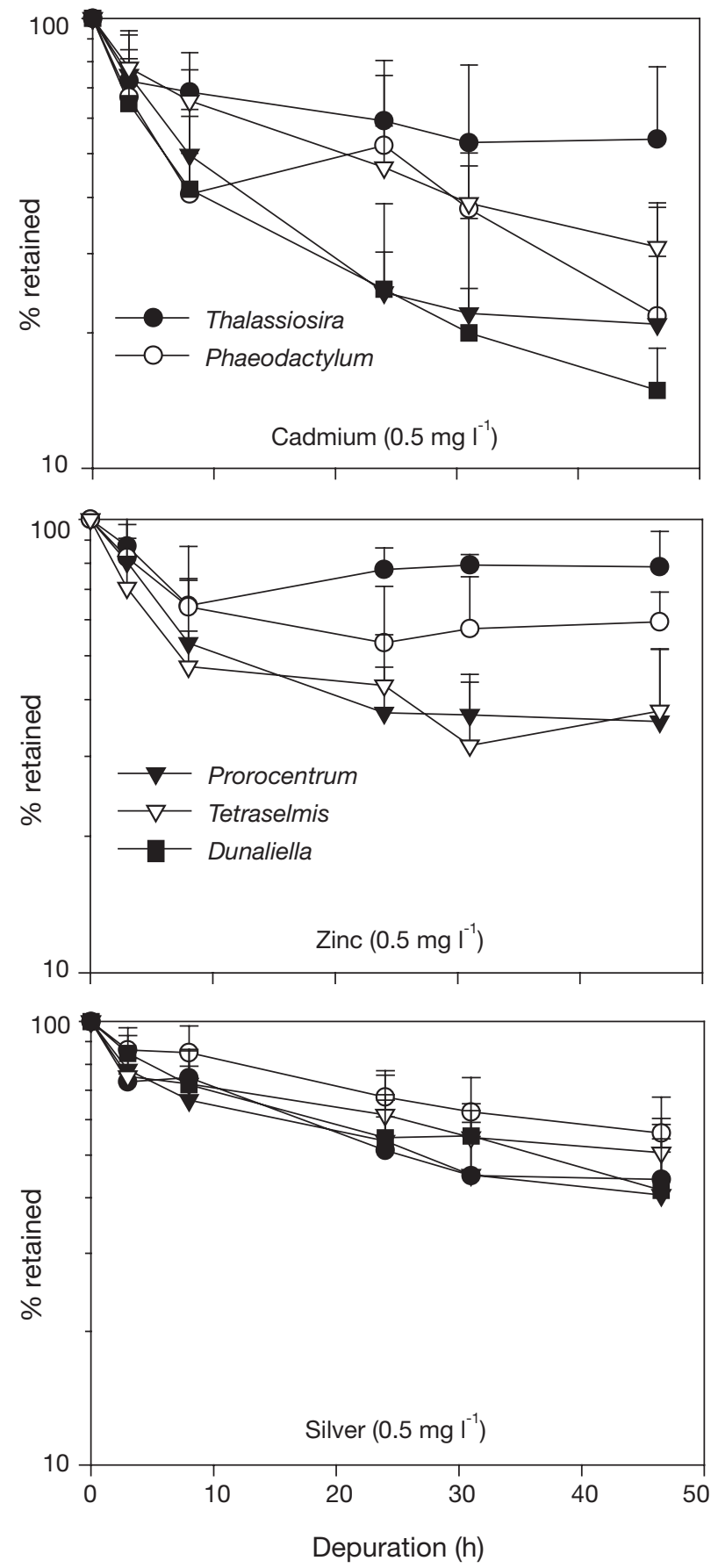

Fig. 5. Balanus amphitrite. Retention of cadmium, zinc and silver by barnacles following pulse-feeding on each of 5 phytoplankton species at $0.5 \mathrm{mg} \mathrm{l}^{-1}$. Means and standard deviations $(\mathrm{n}=8)$

Table 5 presents ratios of the quantities of radiolabelled metals calculated by proportion (Fig. 2) to be in the exchangeable plus soluble fractions in the ingested diet at Time 0 by the clam Ruditapes philippinarum, to those assimilated at $48 \mathrm{~h}$. If this ratio is $<1$, then at least some of the radiolabelled metal assimilated by the 
Table 3. Comparisons (ANOVA or $t$-test) between assimilation efficiencies (AEs) of Cd, Zn and Ag in 3 invertebrates feeding on up to 7 species of phytoplankton, using arcsine-transformed percentage data. Columns under the a posteriori heading sharing the same letter within a row are not significantly different from each other $(p>0.05)$. NS: $p>0.05 ;{ }^{*} p<0.05 ;{ }^{* *} p<0.01 ;{ }^{* * *} p<0.001$

\begin{tabular}{|c|c|c|c|c|c|c|c|c|c|c|}
\hline \multicolumn{11}{|c|}{ (a) AEs of different invertebrates feeding on the same phytoplankton species at $0.5 \mathrm{mg} \mathrm{l}^{-1}$} \\
\hline & \multicolumn{2}{|c|}{ ANOVA ( $t$-test) } & $\begin{array}{c}\text { a priori } \\
\text { p }\end{array}$ & \multicolumn{3}{|c|}{ a posteriori } & & & & \\
\hline \multirow{2}{*}{\multicolumn{11}{|c|}{ Cadmium }} \\
\hline Cadmium & & & & & & & & & & \\
\hline I halassiosira & 5.998 & 2,9 & $0.022^{*}$ & A, B & A & B & & & & \\
\hline Phaeodactylum & 2.625 & 2,7 & 0.141 & A & A & A & & & & \\
\hline Prorocentrum & 9.170 & 2,13 & $0.003^{* *}$ & A & B & B & & & & \\
\hline Tetraselmis & 23.83 & 2,10 & $0.000^{* *}$ & A & A & B & & & & \\
\hline Dunaliella & 99.03 & 2,15 & $0.000^{* *}$ & A & B & B & & & & \\
\hline Isochrysis & 318.4 & 1,6 & $0.000^{* *}$ & A & - & B & & & & \\
\hline Rhodomonas & 166.6 & 1,7 & $0.000^{* *}$ & A & - & B & & & & \\
\hline \multicolumn{11}{|l|}{ Zinc } \\
\hline Thalassiosira & 11.69 & 2,10 & $0.002^{* *}$ & A, B & A & B & & & & \\
\hline Phaeodactylum & 2.059 & 1,3 & 0.247 & A & - & A & & & & \\
\hline Prorocentrum & 7.785 & 2,10 & $0.009^{* *}$ & A & A, B & $\mathrm{B}$ & & & & \\
\hline Tetraselmis & 2.659 & 2,9 & 0.124 & A & A & A & & & & \\
\hline Dunaliella & 11.68 & 2,15 & $0.01^{* *}$ & A & B & $\mathrm{B}$ & & & & \\
\hline Isochrysis & 32.32 & 1,6 & $0.001^{* *}$ & A & - & B & & & & \\
\hline Rhodomonas & 11.65 & 1,3 & $0.042^{*}$ & A & - & A & & & & \\
\hline \multicolumn{11}{|l|}{ Silver } \\
\hline Thalassiosira & $(1.260)$ & 5 & NS & A & A & - & & & & \\
\hline Phaeodactylum & $(1.689)$ & 3 & NS & A & A & - & & & & \\
\hline Prorocentrum & $(1.003)$ & 9 & NS & A & A & - & & & & \\
\hline Tetraselmis & $(1.065)$ & 6 & NS & A & A & - & & & & \\
\hline Dunaliella & $(0.118)$ & 11 & NS & A & A & - & & & & \\
\hline \multicolumn{11}{|c|}{ (b) AEs of 1 invertebrate feeding on different phytoplankton species at $0.5 \mathrm{mg} \mathrm{l}^{-1}$ (low) or $3 \mathrm{mg} \mathrm{l}^{-1}$ (high) } \\
\hline & $F^{\mathrm{ANC}}$ & $\begin{array}{l}V A \\
\text { df }\end{array}$ & $\begin{array}{c}\text { a priori } \\
\mathrm{p}\end{array}$ & Thalassiosira & Phaeodactylum & Prorocentrum & $\begin{array}{c}\text { - a posteriori } \\
\text { Tetraselmis }\end{array}$ & Dunaliella & Isochrysis & Rhodomonas \\
\hline \multicolumn{11}{|l|}{ Cadmium } \\
\hline Perna (low) & 3.180 & 6,23 & $0.020^{*}$ & A & A & A & A & A & A & A \\
\hline Perna (high) & 1.589 & 6,28 & 0.187 & A & A & A & A & A & A & A \\
\hline Ruditapes (low) & 5.325 & 6,15 & $0.002^{* *}$ & $A, B, C$ & $\mathrm{C}$ & $\mathrm{B}, \mathrm{C}$ & $\mathrm{A}, \mathrm{B}, \mathrm{C}$ & A & A, B & $\mathrm{A}, \mathrm{B}, \mathrm{C}$ \\
\hline Balanus (low) & 6.166 & 4,25 & $0.001^{* *}$ & A & A, B & B & A, B & B & - & - \\
\hline \multicolumn{11}{|l|}{ Zinc } \\
\hline Perna (low) & 2.089 & 6,23 & 0.094 & A & A & A & A & A & A & A \\
\hline Perna (high) & 2.624 & 6,24 & $0.042^{*}$ & A & A & A & A & A & A & A \\
\hline Ruditapes (low) & 3.139 & 6,15 & $0.034^{*}$ & A & A & A & A & A & A & A \\
\hline Balanus (low) & 12.12 & 3,18 & $0.000^{* * *}$ & A & - & B & B & B & - & - \\
\hline \multicolumn{11}{|l|}{ Silver } \\
\hline Perna (high) & 4.020 & 6,25 & $0.006^{* *}$ & B & A & $\mathrm{A}, \mathrm{B}$ & $\mathrm{A}, \mathrm{B}$ & $\mathrm{A}, \mathrm{B}$ & $\mathrm{A}, \mathrm{B}$ & $\mathrm{A}, \mathrm{B}$ \\
\hline Ruditapes (low) & 2.157 & 6,16 & 0.103 & A & A & A & A & A & A & A \\
\hline Balanus (low) & 1.612 & 4,26 & 0.201 & A & A & A & A & A & - & - \\
\hline \multicolumn{11}{|c|}{ (c) AEs of Perna viridis feeding on one phytoplankton species at $0.5 \mathrm{mg} \mathrm{l}^{-1}$ (low) and $3 \mathrm{mg} \mathrm{l}^{-1}$ (high) } \\
\hline \multirow[t]{2}{*}{ Taxon } & 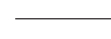 & $-\mathrm{Cad}$ & ium $\longrightarrow$ & - & & Zin & & & & \\
\hline & $t$ & df & $\mathrm{p}$ & Conclusion & $t$ & df & $\mathrm{p}$ & Conclusion & & \\
\hline Thalassiosira & 0.891 & 8 & NS & low $=$ high & 0.358 & 8 & NS & low $=$ high & & \\
\hline Phaeodactylum & 0.541 & 5 & NS & low $=$ high & 0.951 & 5 & NS & low $=$ high & & \\
\hline Prorocentrum & 1.094 & 8 & NS & low $=$ high & 4.234 & 7 & ${ }^{* *}$ & low $<$ high & & \\
\hline Tetraselmis & 0.110 & 8 & NS & low $=$ high & 0.951 & 8 & NS & low $=$ high & & \\
\hline Dunaliella & 0.191 & 8 & NS & low $=$ high & 0.653 & 8 & NS & low $=$ high & & \\
\hline Isochrysis & 1.702 & 7 & NS & low $=$ high & 0.602 & 7 & NS & low $=$ high & & \\
\hline Rhodomonas & 3.944 & 7 & ${ }^{* *}$ & low $>$ high & 2.590 & 4 & NS & low $=$ high & & \\
\hline
\end{tabular}

clam must have been derived from metal bound to the insoluble fraction of the phytoplankton. It is evident from Table 5 that zinc must have been assimilated by R. philippinarum from the insoluble fractions of Phaeo- dactylum tricornutum, Rhodomonas salina and Dunaliella tertiolecta. Cadmium has also been assimilated by the clam from the insoluble fractions in the first 2 of these 3 phytoplankton species and in Thalassiosira 

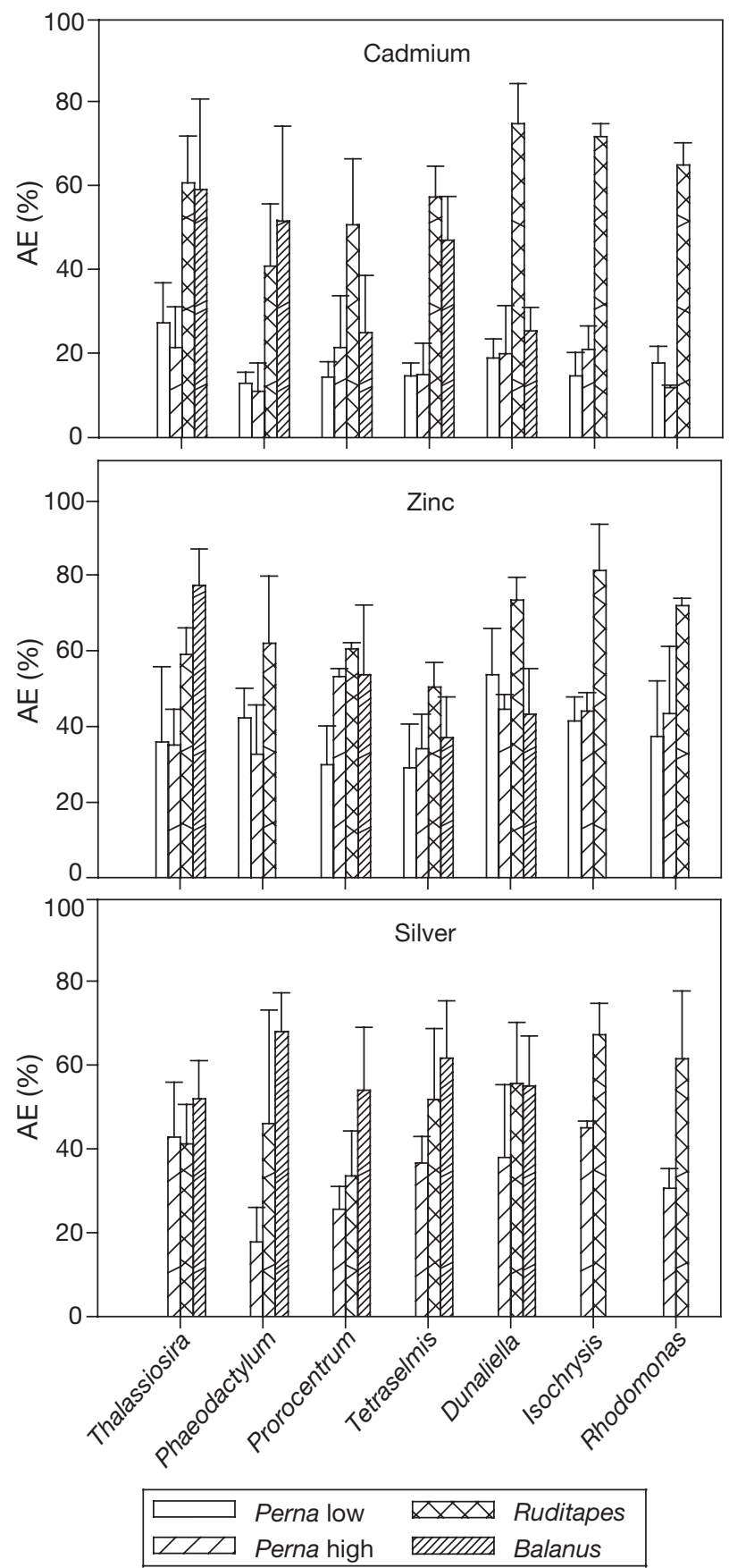

Fig. 6. Assimilation efficiencies (AE, \%) of cadmium, zinc and silver from 7 phytoplankton species in the mussels Perna viridis, clams Ruditapes philippinarum and barnacles Balanus amphitrite. AE experiments for clams and barnacles were conducted at phytoplankton concentrations of $0.5 \mathrm{mg} \mathrm{l}^{-1}$, whereas those for mussels were conducted at both low $\left(0.5 \mathrm{mg} \mathrm{l}^{-1}\right)$ and high $\left(3 \mathrm{mg} \mathrm{l}^{-1}\right)$ phytoplankton concentrations. Means and standard deviations ( $\mathrm{n}=5$ to 8 )

weissflogii (Table 5). In the case of the mussel Perna viridis, this ratio was clearly $<1$ (95\% CL do not overlap 1.0) only for $\mathrm{Zn}$ in specimens fed Prorocentrum minimum $(0.19 \pm 0.05)$. In the barnacle Balanus am-

Table 4. Correlation between the percentage of phytoplankton metal that is exchangeable, soluble, or insoluble versus assimilation efficiencies of the herbivores. Data were fitted with regression models. $\mathrm{R}^{2}$ is the correlation coefficient, and significance of regression coefficient was tested by ANOVA $\left({ }^{*} \mathrm{p}<0.05 ;{ }^{* *} \mathrm{p}<0.01 ;{ }^{* * *} \mathrm{p}<0.001\right)$. Most relationships (40 from 48 ) were not significant (NS), and the remaining 36 are not shown (SE: standard error)

\begin{tabular}{|c|c|c|c|c|}
\hline $\begin{array}{l}\text { Percentage form } \\
\text { of storage }\end{array}$ & $\begin{array}{c}\text { Regression } \\
\text { coefficient }\end{array}$ & SE & ANOVA & $\mathrm{R}^{2}$ \\
\hline \multicolumn{5}{|c|}{ Perna viridis $\left(3 \mathrm{mg} \mathrm{l}^{-1}\right)$} \\
\hline \multicolumn{5}{|l|}{ Silver } \\
\hline Exchangeable & 0.405 & 0.167 & * & 0.164 \\
\hline Soluble & 0.000 & 0.183 & NS & 0.000 \\
\hline Insoluble & -0.585 & 0.148 & *** & 0.342 \\
\hline \multicolumn{5}{|c|}{ Ruditapes philippinarum $\left(0.5 \mathrm{mg} \mathrm{l}^{-1}\right)$} \\
\hline \multicolumn{5}{|c|}{ Cadmium } \\
\hline Exchangeable & -0.244 & 0.198 & NS & 0.595 \\
\hline Soluble & 0.671 & 0.151 & $* * *$ & 0.450 \\
\hline Insoluble & -0.701 & 0.146 & ${ }^{* * *}$ & 0.491 \\
\hline \multicolumn{5}{|c|}{ Balanus amphitrite $\left(0.5 \mathrm{mg} \mathrm{l}^{-1}\right)$} \\
\hline \multicolumn{5}{|l|}{ Cadmium } \\
\hline Exchangeable & -0.372 & 0.175 & * & 0.139 \\
\hline Soluble & -0.127 & 0.187 & NS & 0.016 \\
\hline Insoluble & 0.273 & 0.182 & NS & 0.075 \\
\hline \multicolumn{5}{|l|}{ Zinc } \\
\hline Exchangeable & 0.570 & 0.184 & ${ }^{* *}$ & 0.324 \\
\hline Soluble & -0.602 & 0.178 & ${ }^{* *}$ & 0.363 \\
\hline Insoluble & 0.635 & 0.173 & ${ }^{* *}$ & 0.404 \\
\hline
\end{tabular}

Table 5. Ratios of the quantities of radiolabelled metals calculated to be in exchangeable plus soluble forms ingested by the bivalve Ruditapes philippinarum to the quantities assimilated at $48 \mathrm{~h}$. Mean and confidence intervals at the $95 \%$ level

\begin{tabular}{|lccc|}
\hline Food source & Cadmium & Zinc & Silver \\
\hline Thalassiosira & $0.74 \pm 0.17$ & $0.97 \pm 0.12$ & $1.24 \pm 0.55$ \\
Phaeodactylum & $0.62 \pm 0.32$ & $0.09 \pm 0.04$ & $0.84 \pm 0.40$ \\
Prorocentrum & $0.82 \pm 0.36$ & $0.85 \pm 0.17$ & $1.78 \pm 0.96$ \\
Tetraselmis & $1.47 \pm 0.68$ & $1.75 \pm 1.20$ & $1.16 \pm 0.27$ \\
Dunaliella & $1.13 \pm 0.11$ & $0.85 \pm 0.07$ & $1.36 \pm 0.28$ \\
Isochrysis & $0.97 \pm 0.09$ & $0.92 \pm 0.11$ & $1.19 \pm 0.12$ \\
Rhodomonas & $0.89 \pm 0.07$ & $0.49 \pm 0.08$ & $0.91 \pm 0.25$ \\
\hline
\end{tabular}

phitrite, the ratio was clearly $<1$ only in specimens fed $P$. minimum and then for all 3 metals $(\mathrm{Cd}$ : $0.65 \pm 0.30$; $\mathrm{Zn:} 0.17 \pm 0.10$; Ag: $0.66 \pm 0.08$ ). It can thus be concluded that trace metals bound to the insoluble fraction in phytoplankton can be bioavailable to herbivores.

\section{DISCUSSION}

The choice of the wide systematic range of phytoplankton for this study has been reflected successfully in the observed variation in the trace-metal accumulation powers of the different phytoplankton species and 
in the differential fractionation of the accumulated metals in the phytoplankton cells. The concentration factors of metals in phytoplankton species have been well summarised by Fisher \& Reinfelder (1995). Our measured concentration factors in different phytoplankton species were comparable to those of these previous studies. The features of the cell wall of the phytoplankton may affect metal accumulation. However, the high accumulation ability of Thalassiosira weissflogii may not be solely related to the external features of the diatom or size of the cells, because the other diatom, Phaeodactylum tricornutum, of similar size to T. weissflogii, only accumulated low amounts of metals.

The distribution of accumulated metals on and in the phytoplankton cells, as reflected in the percentage contributions to total content of exchangeable, soluble and insoluble incorporated metals, was extremely variable. In our study, most $\mathrm{Cd}$ and $\mathrm{Zn}$ were incorporated into all the phytoplankton cells as opposed to remaining in exchangeable form externally. Incorporated $\mathrm{Cd}$ and $\mathrm{Zn}$ were predominantly in insoluble form in the 2 diatoms and in the dinoflagellate, and were mostly soluble in the remaining species. In fact, the insoluble component of incorporated metal includes metal tightly bound to cell walls and cell debris, as well as to specific metal-binding insoluble deposits, such as phosphate granules or lysosomal residual bodies. In addition, the siliceous frustule of the diatom cell walls may incorporate $\mathrm{Cd}$ and $\mathrm{Zn}$ strongly, contributing to the high percentage in the insoluble fraction. However, the reason for the similar distribution in the dinoflagellate is still unclear. Metal in the exchangeable component was much more evident for silver. This is probably due to the high particle reactivity of silver, which, once it was incorporated into the cells, distributed relatively evenly between soluble and insoluble forms in all phytoplankton.

The AEs of $\mathrm{Cd}$ and $\mathrm{Zn}$ showed significant variation between the 3 invertebrates feeding on the same phytoplankton species at the same concentration, while Ag AE did not differ significantly between Ruditapes philippinarum and Balanus amphitrite feeding on the same phytoplankton (Table 3). The AEs of $R$. philippinarum were usually the highest and those of Perna viridis the lowest, in agreement with earlier work (Chong \& Wang 2001, Shi et al. 2003, Ng \& Wang 2004). Barnacles, including B. amphitrite, are considered to have high AEs in comparison to many invertebrates (Wang et al. 1999a, b, Wang \& Rainbow 2000, Rainbow \& Wang 2001), and so the AEs of R. philippinarum are particularly high.

The differential assimilation of trace metals by invertebrates from different phytoplankton diets is well established, notably in bivalve molluscs (Wang \& Fisher 1999) including Perna viridis and Ruditapes philippinarum (Chong \& Wang 2000) and barnacles (Wang \& Rainbow 2000, Rainbow \& Wang 2001). $P$. viridis, in fact, showed no differential assimilation of $\mathrm{Cd}$ and $\mathrm{Zn}$ between phytoplankton diets at 0.5 or $3 \mathrm{mg}$ $\mathrm{l}^{-1}$ (Table 3). R. philippinarum showed differential assimilation of $\mathrm{Cd}$ between phytoplankton at $0.5 \mathrm{mg}$ $\mathrm{l}^{-1}$, but not of $\mathrm{Zn}$ or Ag (Table 3). Balanus amphitrite only fed on 5 of the 7 phytoplankton species, but still showed differences between phytoplankton for AEs of $\mathrm{Cd}$ and $\mathrm{Zn}$, but not Ag (Table 3).

In oysters fed $\mathrm{Cu}$-enriched diatoms (Haslea ostrearia), it has been shown that the percentage of metal retained by bivalves increased from 13 to $79 \%$ and to $93 \%$ after 1,2 and $3 \mathrm{wk}$ of experimental feeding, respectively (Ettajani et al. 1992). Temporal changes in $\mathrm{Cu}$ retention in oysters may be attributed to differential absorption of biochemical components by these bivalves in response to changes in their food regime, as shown in other species, Mytilus chilensis and Mulinia edulis. When their typical diets were changed, over a period of $7 d$, the energy absorbed declined by $32 \%$ in M. chilensis and $64 \%$ in M. edulis (Navarro et al. 2003). However, absorption efficiency involved acclimation (which was not completed at Day 7), indicating the capacity of these species to modulate their enzymatic-digestive activity depending on food composition (Labarta et al. 2002). In the present work the filter feeders had been fed diatoms (Thalassiosira weissflogii) during acclimation in the laboratory. There was no evidence that the AEs of any of the 3 metals was raised significantly when the experimental food source was also T. weissflogii, although the AE of each metal when an invertebrate was feeding on $T$. weissflogii was the highest $\mathrm{AE}$ in all but 1 case.

This study set out to seek generalities in the relationships between metal partitioning in phytoplankton and their subsequent assimilation in filter-feeding herbivores. Reinfelder \& Fisher (1991) concluded that metal assimilation in copepods is directly related to the metal bound in the cytoplasm of a diatom (Thalassiosira pseudonana). Wang \& Rainbow (2000) and Rainbow \& Wang (2001) provided some support for this conclusion as a general principle in the barnacles Balanus trigonus and Elminius modestus, respectively. In $B$. trigonus the AEs of $\mathrm{Cd}$ and $\mathrm{Zn}$ (but not Ag) were correlated with the percentage of metal present in the cytoplasm of 4 dietary phytoplankton species (Wang \& Rainbow 2000), while in E. modestus the AEs of Cd and Se (but not $\mathrm{Zn}$ or $\mathrm{Cr}$ ) showed the same correlation, in this case for 5 phytoplankton species as diets. There was also a significant correlation between the AEs of $\mathrm{Am}, \mathrm{Co}$ and Se in the mussel Mytilus edulis and the cytosolic distribution in the natural seston (Wang et al. 1996) or the diatom T. pseudonana (Wang \& Fisher 1996), but this did not apply to Ag, Cd and Zn (Wang \& 
Fisher 1996, Wang et al. 1996). In addition, the percentages of Ag, Am, Cd, Co, Se and $\mathrm{Zn}$ assimilated by $M$. edulis were positively related to the cytoplasmic fraction in ingested Isochrysis galbana cells, as they were for $\mathrm{Ag}$ and $\mathrm{Cd}$ in the oyster Crassostrea virginica and the clams Macoma balthica and Mercenaria mercenaria (Reinfelder et al. 1997).

Before we discuss the relationships found in this study, it is necessary to compare our fractionation scheme with ones previously used. Conventional studies have often focused on the bioavailability of intracellular/cytoplasmic metals. Our study has also investigated the bioavailability of metals adsorbed onto the cell walls, as identified by extraction with a metal-complexing agent. Among the different metal-complexing agents that have been used to discriminate between intra- and extracellular metals, 8-hydroxyquinoline5 -sulfonic acid has been regarded to have the smallest effect on membrane permeability (Hassler et al. 2004). This ensures that no initially intracellular labelled metal will be lost during the first step of fractionation, and 8-hydroxyquinoline-5-sulfonic acid was, therefore, chosen as the complexing agent to be used here. Furthermore, the phytoplankton fractions were classified in this study into groups that differ from those in other studies. Reinfelder \& Fisher (1991) separated the phytoplankton into 3 fractions - a cell-wall fraction, a heavy organelles fraction and cytoplasm. Other studies have separated the cells into 2 fractions - a cell-wall fraction and the cytoplasm (including heavy organelles) (Reinfelder \& Fisher 1991, Wang \& Fisher 1996, Chong \& Wang 2000). By comparing the different speeds of centrifugation used, it remains possible that the combined cell-wall fraction and heavy organelles used by Reinfelder \& Fisher (1991) may be equivalent to our insoluble fraction, and their cytoplasm may be equivalent to our soluble fraction.

The choice of 7 phytoplankton species from a wide systematic range has provided a wide range of percentage accumulated metal contents in the different fractions separated, but the study has failed to establish the generalities hinted at in earlier, more restricted studies. As perhaps is inevitable in such a large study, a few significant relationships were demonstrated, but these were inconsistent and sometimes contradictory (Table 4). Xu \& Wang (2004) reported that a few important processes are responsible for Ag assimilation, including its distribution in different subcellular fractions (e.g. cytoplasmic), concentration factor in the phytoplankton and particle reactivity (e.g. tendency to bind with particles), and gut passage time. In general, soluble metal is important for determining metal assimilation in the herbivores, as also shown for the cadmium uptake in Ruditapes philippinarium and the zinc uptake in Balanus amphitrite in our study. There is, however, no support for a generalised conclusion that any of the 3 fractions isolated represents that form of phytoplankton metal that is bioavailable for trophic transfer to a herbivore.

This study has also shown that even trace metals bound to the insoluble fraction in phytoplankton can be bioavailable to herbivores. Similarly, some of the accumulated trace metal bound to the insoluble fraction in animal prey has been shown to be bioavailable to predators. The decapod crustacean Palaemonetes pugio fed $\mathrm{Cd}$-contaminated oligochaete worms assimilated $48.6 \%$ of the $\mathrm{Cd}$ bound to a subcellular debris fraction that included granules and tissue fractions, although this AE was not as high as the $\mathrm{AE}$ of $84.8 \%$ from the cytosolic fraction (Wallace \& Lopez 1997). Wallace et al. (2003) have also indicated that, in addition to any metal bound to protein, metal bound to organelles in the bivalves Macoma balthica and Potamocorbula amurensis may also be trophically available. Furthermore, Cheung \& Wang (2005) have shown that metals in metal-rich granules that are in the insoluble fraction of prey can be bioavailable to the gastropod Thais clavigera. In oysters, a significant fraction of the trace metals stored in insoluble form may be released during in vitro digestion (silver: 35 to $63 \%$; cadmium: 30 to $48 \%$; zinc: 70 to $88 \%$ ) (Bragigand et al. 2004). Even sediment-bound metals may be partly available to filter or deposit feeders using incubation of sediments with digestive fluids from different species of marine benthic invertebrates (Mayer et al. 2001, Fan et al. 2002, Yan \& Wang 2002, Weston et al. 2004). In mussels (Mytilus edulis) fed various sediments, silver AE varied from 4.6 to $23 \%$, cadmium AE from 9.5 to $35 \%$ and zinc AE from 21 to $36 \%$ (Griscom et al. 2000).

The opportunity was taken to compare the AEs of cadmium and zinc in Perna viridis at 2 diet concentrations - at $0.5 \mathrm{mg} \mathrm{l}^{-1}$, representing typical phytoplankton concentrations in Hong Kong coastal waters, and at $3 \mathrm{mg} \mathrm{l}^{-1}$, below the phytoplankton concentration at which green mussels produce pseudofaeces. Essentially there was no effect of diet on cadmium or zinc AE. The 2 exceptions (Table 3c) were contradictory in the diet concentration that was associated with the higher AE. The AEs of cadmium and zinc have been found to be dependent on the food composition and food concentration, respectively, in the mussels. The $\mathrm{AE}$ of $\mathrm{Cd}$ in the mussel Mytilus trossulus from silt particles increased from $36 \%$ at $50 \mathrm{mg} \mathrm{l}^{-1}$ of silt to $92 \%$ with the addition of 20000 cells ml ${ }^{-1}$ of the diatom Thalassiosira pseudonana (Arifin \& Bendell-Young 2000). Chong \& Wang (2000) found that the presence of sediment reduced $\mathrm{Cd}$ assimilation from ingested diatoms by green mussels Perna viridis. In addition, an increase in food concentration from 1 to $15 \mathrm{mg} \mathrm{l}^{-1}$ during diges- 
tion of $P$. viridis resulted in a significant decrease in the AE of zinc bound in either sediments or diatoms (Wong \& Wang 2003). In our study, the food concentration may not have been high enough for such effects to be observed on the AE of zinc.

In conclusion, therefore, the physico-chemical form of trace metals accumulated by phytoplankton does not control their assimilation by filter-feeding invertebrates, at the relatively crude level of distinction into exchangeable, soluble and insoluble fractions. Differential bioavailabilities of trace metals in the diet are therefore controlled by more subtle differences in the form of chemical binding of the accumulated metals in the phytoplankton. It is not possible to draw a generalised conclusion that any of the 3 fractions isolated in our study represents that form of phytoplankton metal that is bioavailable for trophic transfer to a herbivore.

Acknowledgements. This study was supported by a Competitive Earmarked Research Grant from the Hong Kong Research Grants Council (HKUST6097/02M) awarded to W.-X.W.

\section{LITERATURE CITED}

Amiard-Triquet C, Jeantet AY, Berthet B (1993) Metal transfer in marine food chains. Acta Biol Hung 44:387-409

Arifin Z, Bendell-Young LI (2000) Feeding response and carbon assimilation by the blue mussel Mytilus trossulus exposed to environmentally relevant seston matrices. Mar Ecol Prog Ser 160:241-253

Bragigand V, Berthet B, Amiard JC, Rainbow PS (2004) Estimates of trace metal bioavailability to humans ingesting contaminated oysters. Food Chem Toxicol 42:1893-1902

Cheung MS, Wang WX (2005) Influence of subcellular metal compartmentalization in different prey on the transfer of metals to a predatory gastropod. Mar Ecol Prog Ser 286: 155-166

Chong K, Wang WX (2000) Assimilation of Cd, Cr and Zn by the green mussel Perna viridis and the clam Ruditapes philippinarum. Environ Toxicol Chem 19:1660-1667

Chong K, Wang WX (2001) Comparative studies on the biokinetics of $\mathrm{Cd}, \mathrm{Cr}$, and $\mathrm{Zn}$ in the green mussel Perna viridis and the Manila clam Ruditapes philippinarum. Environ Pollut 115:107-121

Ettajani H, Amiard-Triquet C, Amiard JC (1992) Etude expérimentale du transfert de deux éléments traces $(\mathrm{Ag}, \mathrm{Cu})$ dans une chaîne trophique marine: eau - particules (sédiment naturel, microalgue) - mollusques filtreurs (Crassostrea gigas Thunberg). Water Air Soil Pollut 65: 215-236

Ettajani H, Berthet B, Amiard JC, Chevolot L (2001) Determination of cadmium partitioning in microalgae and oysters: contribution to the assessment of trophic transfer. Arch Environ Contam Toxicol 40:209-221

Fan W, Wang WX, Chen J (2002) Speciation of Cd, Cr, and Zn in highly contaminated sediments and its influences on assimilation by marine bivalves. Environ Sci Technol 36: $5164-5171$

Fisher NS, Reinfelder JR (1995) The trophic transfer of metals in marine systems. In: Tessier A, Turner DR (eds) Metal speciation and bioavailability in aquatic systems. John Wiley \& Sons, Chichester, p 363-406

Fisher NS, Burns KS, Cherry RD, Heyraud M (1983) Accumulation and cellular distribution of ${ }^{241} \mathrm{Am},{ }^{210} \mathrm{Po}$, and ${ }^{210} \mathrm{~Pb}$ in two marine algae. Mar Ecol Prog Ser 11:233-237

Griscom SB, Fisher NS, Luoma SN (2000) Geochemical influences on assimilation of sediment-bound metals in clams and mussels. Environ Sci Technol 34:91-99

Guillard RRL, Ryther JH (1962) Studies of marine planktonic diatoms. 1. Cyclotella nana Hustedt and Detonula confervacea (Cleve) Gran. Can J Microbiol 8:229-239

Hassler CS, Slaveykova VI, Wilkinson KJ (2004) Discriminating between intra- and extracellular metals using chemical extractions. Limnol Oceanogr Methods 2:237-247

Hutchins DA, Wang WX, Fisher NS (1995) Copepods grazing and the biogeochemical fate of diatom iron. Limnol Oceanogr 40:989-994

Labarta U, Fernandez-Reiriz J, Navarro A, Velasco A (2002) Enzymatic digestive activity in epifaunal (Mytilus chilensis) and infaunal (Mulinia edulis) bivalves in response to changes in food regimes in a natural environment. Mar Biol 140:669-676

Mayer LM, Weston DP, Bock MJ (2001) Benzo[a]pyrene and zinc solubilization by digestive fluids of benthic invertebrates - a cross-phyletic study. Environ Toxicol Chem 20: $1890-1900$

Navarro JM, Labarta U, Fernandez-Reiriz MJ, Velasco A (2003) Feeding behavior and differential absorption of biochemical components by the infaunal bivalve Mulinia edulis and the epibenthic Mytilus chilensis in response to changes in food regimes. J Exp Mar Biol Ecol 287:13-35

Ng TYT, Wang WX (2004) Detoxification and effects of Ag, $\mathrm{Cd}$, and $\mathrm{Zn}$ pre-exposure on metal uptake kinetics in the clam Ruditapes philippinarum. Mar Ecol Prog Ser 268: 161-172

Price NM, Morel FMM (1990) Cadmium and cobalt substitution for zinc in a marine diatom. Nature 344:658-660

Rainbow PS, Wang WX (2001) Comparative assimilation of $\mathrm{Cr}, \mathrm{Cr}$, Se, and $\mathrm{Zn}$ by the barnacle Elminius modestus from phytoplankton and zooplankton diets. Mar Ecol Prog Ser 218:239-248

Rainbow PS, Blackmore G, Wang WX (2003) Effects of previous field exposure history on the uptake of trace metals from water and food by the barnacle Balanus amphitrite. Mar Ecol Prog Ser 259:201-213

Rainbow PS, Ng TYT, Shi D, Wang WX (2004) Acute dietary pre-exposure and trace metal bioavailability to the barnacle Balanus amphitrite. J Exp Mar Biol Ecol 311: 315-337

Reinfelder JR, Fisher NS (1991) The assimilation of elements ingested by marine copepods. Science 251:794-796

Reinfelder JR, Wang WX, Luoma SN, Fisher NS (1997) Assimilation efficiencies and turnover rates of trace elements in marine bivalves: a comparison of oysters, clams and mussels. Mar Biol 129:443-452

Shi D, Wang WX (2004) Modification of trace metal accumulation in the green mussel Perna viridis by exposure to Ag, $\mathrm{Cu}$, and $\mathrm{Zn}$. Environ Pollut 132:265-277

Shi D, Blackmore G, Wang WX (2003) Effects of aqueous and dietary pre-exposure and resulting body burden on silver biokinetics in the green mussel Perna viridis. Environ Sci Technol 37:936-943

Wallace WG, Lopez GR (1997) Bioavailability of biologically sequestered cadmium and the implications of metal detoxification. Mar Ecol Prog Ser 147:149-157

Wallace WG, Lee BG, Luoma SN (2003) Subcellular compartmentalization of $\mathrm{Cd}$ and $\mathrm{Zn}$ in two bivalves. I. Significance 
of metal-sensitive fractions (MSF) and biologically detoxified metal (BDM). Mar Ecol Prog Ser 249:183-197

Wang WX (2002) Interactions of trace metals and different marine food chains. Mar Ecol Prog Ser 243:295-309

Wang WX, Fisher NS (1996) Assimilation of trace elements and carbon by the mussel Mytilus edulis: effects of food composition. Limnol Oceanogr 41:197-207

Wang WX, Fisher NS (1999) Assimilation efficiencies of chemical constituents in aquatic invertebrates: a synthesis. Environ Toxicol Chem 18:2034-2045

Wang WX, Rainbow PS (2000) Dietary uptake of Cd, Cr, and $\mathrm{Zn}$ in the barnacle Balanus trigonus: influence of diet composition. Mar Ecol Prog Ser 204:159-168

Wang WX, Wong SK (2003) Combined effects of food quantity and quality on $\mathrm{Cd}, \mathrm{Cr}$, and $\mathrm{Zn}$ assimilation to the green mussel, Perna viridis. J Exp Mar Biol Ecol 290:49-69

Wang WX, Fisher NS, Luoma SN (1996) Kinetic determinations of trace element bioaccumulation in the mussel Mytilus edulis. Mar Ecol Prog Ser 140:91-113

Editorial responsibility: Otto Kinne (Editor-in-Chief), Oldendorf/Luhe, Germany
Wang WX, Qiu JW, Qian PY (1999a) The trophic transfer of $\mathrm{Cd}, \mathrm{Cr}$, and Se in the barnacle Balanus amphitrite from planktonic food. Mar Ecol Prog Ser 187:191-201

Wang WX, Qiu JW, Qian PY (1999b) Significance of trophic transfer in predicting the high concentration of zinc in barnacles. Environ Sci Technol 33:2905-2909

Weston DP, Judd JR, Mayer LM (2004) Effect of extraction conditions on trace element solubilization in deposit feeder digestive fluid. Environ Toxicol Chem 23: 1834-1841

Xu Y, Wang WX (2002) The assimilation of detritus-bound metals by the marine copepod Acartia spinicauda. Limnol Oceanogr 47:604-610

Xu Y, Wang WX (2004) Silver uptake by a marine diatom and its transfer to the coastal copepod Acartia spinicauda. Environ Toxicol Chem 23:682-690

Yan QL, Wang WX (2002) Metal exposure and bioavailability to a marine deposit-feeding sipuncula Sipunculus nudus. Environ Sci Technol 36:40-47

Submitted: January 4, 2005; Accepted: April 12, 2005

Proofs received from author(s): August 16, 2005 